\title{
Effect of Quality of Accounting Information and Asymmetric Information on the Cost of Capital (Case Study on the Indonesia Stock Exchange)
}

\author{
Eli Safrida \\ Politeknik Negeri Medan \\ Riswanto \\ Politeknik Negeri Medan \\ Meily Surianti \\ Politeknik Negeri Medan
}

\begin{abstract}
This study aims to obtain empirical evidence regarding the factors that affect the cost of capital on the Indonesia Stock Exchange. In addition, the results of the study are expected to obtain insights, knowledge and empirical evidence regarding investor behavior in the Indonesian capital market. The results of the study mainly contribute to the fields of financial accounting, accounting theory, financial management and investment management portfolio analysis. Research results can be developed to be the basis for making case studies in the learning process. The data used is secondary data, which comes from the annual financial statements of manufacturing companies listed on the IDX. The hypothesis are tested by using the path analysis statistical test. From the results of hypothesis testing it is found that: the quality of accounting information has no effect on asymmetric information., the quality of accounting information does not affect the cost of capital., asymmetric information affects the cost of capital.. The direct effect of the quality of accounting information on the cost of capital is greater than the effect of The quality of accounting information through asymmetric information.
\end{abstract}

Keywords: information system quality, asymmetric information, cost of capital

DOI: $10.7176 / \mathrm{EJBM} / 12-3-18$

Publication date: January $31^{\text {st }} 2020$

\section{Background of Study}

Financial statements are one of the tools used by market participants to assess the performance of a company, and is a communication tool by company management with investors. Accounting figures reported by companies are one of the most important sources of information for investors' decisions regarding stock prices (Breton and Taffler, 1995).

In addition to providing quality accounting information, how to minimize asymmetric information is also a topic that is widely discussed in many studies. Small asymmetric information is suspected to reduce the cost of capital. Asymmetric information is a condition in which managers as insider have more private information than parties outside the company (such as investors, creditors, analysts, etc.). This asymmetric information is related to information risk and is a component of the cost of capital. The quality of accounting information refers to the accuracy / precision of the information contained in financial statements, while asymmetric information refers to the distribution of information, both the distribution of information between management as an insider party and investors as an outsider party, as well as the distribution of information among investors / shareholders (Lambert, et al., 2008; Battacharya, et al., 2012).

In addition to the quality of accounting information, several studies have also tried to prove the effect of asymmetric information on the cost of capital, both as a stand-alone variable, and as a mediating variable between the quality of accounting information and the cost of capital. Among these are Amihud and Mendelson (1986), Diamond and Verrechia (1991), Dierkens (1991), Easley and O'Hara (2004), Hughes, et al., (2007), Battacharya, et al., (2012) and Barth, et al., (2013). 
Based on the phenomena, this study tries to get empirical evidence about the influence of the quality of accounting information and asymmetric information on the cost of capital. Companies that are the subject of research are manufacturing companies listed on the IDX. The choice of manufacturing companies as research subjects is because manufacturing companies are companies that require very large capital to invest in their assets, so the possibility of requiring outside funding is greater than companies from other sectors.

\section{Literature Review Pecking Order Theory}

Myers and Majluf (1984) stated that the main problem of a company's capital structure decision was asymmetric information between managers and investors about the company's internal conditions, and the argument that managers were in favor of old shareholders. Both of these problems cause the company to have a funding hierarchy that starts from internal cash flow, debt, then shares.

In developing their model, Myers and Majluf (1984) consider that a company must issue a common stock to increase cash to seek valuable investment opportunities. Management is assumed to know more about the value of the company than potential investors. Investors interpret the company's actions rationally. Myers and Majluf (1984) developed an equilibrium model of investment decisions with these assumptions. The model shows that the company may refuse to issue shares, and further misses valuable investment opportunities. The model provides an explanation of several aspects of corporate funding behavior, including the tendency to rely on internal funding sources, and prefer debt over equity if external sources of funds are needed.

Myers and Majluf (1984) argue that equity is the least preferred means of increasing capital because when managers (who are assumed to know more about the true condition of the company than investors) issue new equity, investors believe that managers think that companies are overvalued and managers are take advantage of this over-valuation. As a result, investors will place a lower value for the issuance of new equity.

In an efficient market, with a rich information environment, all existing information is reflected in stock prices. Therefore, in a market with a low level of asymmetric information, the market should become more liquid, because the company will not hesitate to issue equity as a means to obtain capital, because the cost of capital to be borne will be lower. For this reason, management is very interested in providing quality accounting information, which will reduce the information gap between management and investors.

\section{Quality of Accounting Information and Cost of Capital}

Capital markets that attract investors are capital markets that can provide adequate information for potential investors to assess the risk that will be borne for each investment chosen. Accounting information is one of the most important information, which is used by investors as a basis for estimating investment risks, and then will make decisions related to those investments. Quality accounting information is information that can be used as an accurate basis for estimating the investment risk. And to be categorized as quality accounting information, the accounting information must be relevant, reliable, easy to understand, and can be compared, both between companies and between periods.

Presentation of quality accounting information, will increase investor confidence to invest its resources, because the uncertainty that will be faced by investors will be smaller. This trust will cause trade liquidity to increase, so companies can get capital for their investments at lower costs.

In some of the literature mentioned, in a market with perfect competition, the quality of accounting information can directly affect the cost of capital, because all the information that is reflected in stock prices. This can happen because in a market with perfect competition, the market is assumed to be efficient, and all market participants are rational parties. All market participants have equal access to all information, and will immediately make adjustments for any changes that occur.

\section{Asymmetric information and cost of capital}

In an information-rich environment, as in developed countries, with efficient market conditions, asymmetric information between management and investors can be minimized. In an efficient market, available information 
reflects past values, present values, and future values. In such an environment, public disclosure (whether using formal channels such as annual financial reports or other channels) plays an intermediary role in which management signals private information to stakeholders, including investors.

Minimal asymmetric information will increase investor confidence in investment decision making, and will increase capital traffic on the capital market. Increased capital traffic means an increase in trade liquidity, and this will reduce the cost of capital.

By using the pecking order theory approach, the capital market with low asymmetric information will make the capital market an alternative fundraising that is cheaper than debt. This causes the company's management to make raising funds from equity as a more important alternative compared to other sources. This will increase capital market liquidity, and reduce the cost of capital.

\section{Research Methods}

According to the nature of the problem, this research is a descriptive study. Descriptive research is research that aims to describe systematically, factually, and accurately about a situation, situation or field of study that is the object of research. The description results can be quantitative or qualitative or both. (Sekaran and Bougie, 2013). Descriptive research attempts to systematically and carefully provide the actual facts and the nature of a particular population.

The main characteristic of this method is that the researcher has no control over variables. Researchers can only report what has happened or what is happening. Most of this descriptive research is used in ex post facto research projects, where researchers will look for ways to measure the variables to be examined. (Kothari, 2004). The unit of analysis of this research is the annual financial statements of companies listed on the Indonesia Stock Exchange and the monthly stock trading reports of the same company. Data taken from annual financial statements and data from monthly stock trading reports will be tabulated to be processed and statistically tested for later conclusions. The tabulated data is time series data, in which in this study the tabulated data is data from financial reports and stock trading reports for four years.

The study population is companies listed on the IDX except companies from the financial sector. Companies that are sampled are companies that meet the criteria as: (1) listed on the IDX during the observation period, from 2011 - 2018; and (2) has financial statements during the observation period. The analytical method that will be used in this study is path analysis. Path analysis is a development technique of multiple linear regression. This technique is used to test the amount of the contribution (contribution) shown by the path coefficient on each path diagram of the causal relationship between the variable $\mathrm{X}$ to $\mathrm{Y}$ and its impact on $\mathrm{Z}$. Regression is imposed on each variable in a model as the dependent variable (respondent) is being other causes. Regression weighting is predicted in a model that is compared with the observed correlation matrix for all variables and the statistical alignment test is also calculated. This study will examine the effect of the quality of accounting information on asymmetric information, the effect of the quality of accounting information directly on the cost of capital, the effect of asymmetric information on the cost of capital, and the effect of the quality of accounting information on the cost of capital through asymmetric information.

\section{Research Results}

Table 1. Descriptive Statistics

Descriptive Statistics

\begin{tabular}{|l|r|r|r|r|r|}
\hline & N & Minimum & Maximum & \multicolumn{1}{c|}{ Mean } & $\begin{array}{c}\text { Std. } \\
\text { Deviation }\end{array}$ \\
\hline Quality of Information $(\mathrm{X})$ & 1239 & -.24 & 60.00 & 3.4435 & 10.72786 \\
Asymmetry Information $(\mathrm{Y})$ & 1239 & -.25 & 1.01 & .0562 & .10166 \\
Cost of Capital (Z) & 1239 & -22.15 & 53.66 & 10.2414 & 4.41819 \\
Valid N (listwise) & 1239 & & & & \\
\hline
\end{tabular}

The average value for the variable quality of accounting information and asymmetric information respectively 
3.4435 and 0.562 while the standard deviations are 10.72786 and .10166 , respectively.

Path Analysis

1. Calculate the path coefficient

a. Model I Path coefficient

Table 2.

\section{Coefficients(a)}

\begin{tabular}{|c|c|c|c|c|c|c|}
\hline \multicolumn{2}{|c|}{ Model } & \multicolumn{2}{|c|}{$\begin{array}{l}\text { Unstandardized } \\
\text { Coefficients }\end{array}$} & \multirow{2}{*}{$\begin{array}{c}\text { Standardized } \\
\text { Coefficients } \\
\text { Beta }\end{array}$} & \multirow{2}{*}{$\frac{t}{B}$} & \multirow{2}{*}{$\begin{array}{c}\text { Sig. } \\
\text { Std. Error }\end{array}$} \\
\hline & & B & Std. Error & & & \\
\hline \multirow[t]{2}{*}{1} & (Constant) & .056 & .003 & & 18.608 & .000 \\
\hline & $\begin{array}{l}\text { Quality of Information } \\
\text { (X) }\end{array}$ & $\begin{array}{r}-7.63 \mathrm{E}- \\
005\end{array}$ & .000 & -.008 & -.283 & .777 \\
\hline
\end{tabular}

a Dependent Variable:Asymmetry Information (Y)

Based on the tebel above, it can be seen that the significance value of the Information Quality (X) variable is 0.777 which is greater than 0.05 , so it can be concluded that Regression Path I has no effect on Asymmetric Information (Y).

Table 3. Model Summary

\section{Model Summary}

\begin{tabular}{|l|r|r|r|r|}
\hline Model & $\mathrm{R}$ & $\mathrm{R}$ Square & \multicolumn{1}{|c|}{$\begin{array}{c}\text { Adjusted R } \\
\text { Square }\end{array}$} & \multicolumn{1}{c|}{ Std. Error of the Estimate } \\
\hline 1 & $.008(\mathrm{a})$ & .000 & -.001 & .10170 \\
\hline
\end{tabular}

a Predictors: (Constant), Quality of Informationi (X)

R Square value shows the number 0.000 , this shows that there is no contribution of the influence of Information Quality (X) on Asymmetric Information (Y) of $0 \%$. while the value of e1 can be determined by the formula e1 = $\sqrt{ }(1-0.000)=1$

Thus, the following picture can be obtained:

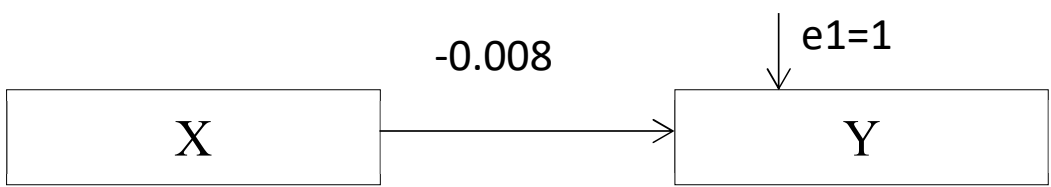

b. Model 2 Road Coefficient 
Table 4. Coefficients

\section{Coefficients(a)}

\begin{tabular}{|ll|r|r|r|r|r|}
\hline \multicolumn{2}{|l|}{ Model } & \multicolumn{2}{|c|}{$\begin{array}{c}\text { Unstandardized } \\
\text { Coefficients }\end{array}$} & $\begin{array}{c}\text { Standardized } \\
\text { Coefficients }\end{array}$ & $\mathrm{t}$ & Sig. \\
\hline & & \multicolumn{1}{|c|}{$\mathrm{B}$} & Std. Error & Beta & $\mathrm{B}$ & Std. Error \\
\hline 1 & (Constant) & 10.431 & .149 & & 70.240 & .000 \\
& Quality of Information $(\mathrm{X})$ & .013 & .012 & .031 & 1.099 & .272 \\
& Asymmetry Information $(\mathrm{Y})$ & -4.158 & 1.230 & -.096 & -3.381 & .001 \\
\hline
\end{tabular}

a Dependent Variable: Cost of Capital (Z)

Based on the table above, it can be seen that the significance value of the two variables namely Information Quality $(\mathrm{X})=0.272$ is greater than 0.05 and Asymmetric Information $(\mathrm{Y})=0.001$ is smaller than 0.05 . This shows that Information Quality (X) does not affect the Cost of Capital (Z) while Asymmetric Information (Y) does

Table 5. Model Summary

\section{Model Summary}

\begin{tabular}{|c|c|c|c|c|}
\hline Model & $\mathrm{R}$ & R Square & $\begin{array}{l}\text { Adjusted R } \\
\text { Square }\end{array}$ & $\begin{array}{l}\text { Std. Error of the } \\
\text { Estimate }\end{array}$ \\
\hline 1 & $.101(a)$ & .010 & .009 & 4.39922 \\
\hline
\end{tabular}

a Predictors: (Constant), Asymmetry Information (Y), Quality of Information (X)

$\mathrm{R}$ Square value shows the number 0.010 , this shows that the contribution of $\mathrm{X}$ and $\mathrm{Y}$ to $\mathrm{Z}$ is $1 \%$. As for the value of $\mathrm{e} 2=\square(1-0.010)=0.9949$.

Thus the following picture can be obtained:

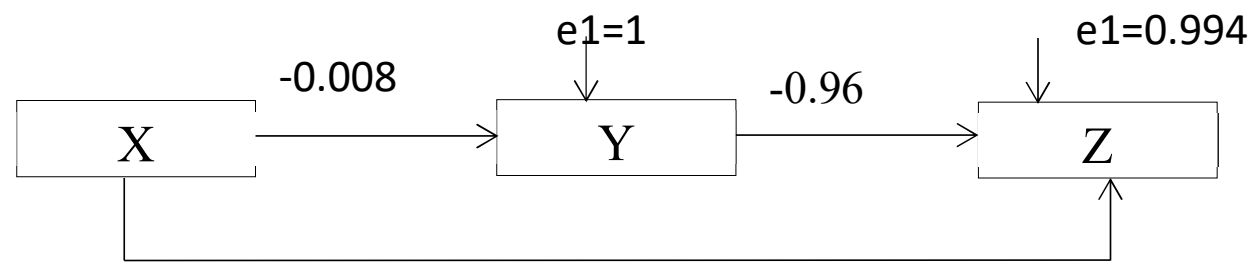

\subsection{1}

\section{Discussion}

The standard error of the estimate is .10170 (the unit used is the dependent variable, that is, asymmetric information). It can be seen that the standard error value of the estimate is almost the same as the standard deviation value of asymmetric information, which means the regression model is equally good in acting as a predictor of asymmetric information compared to the average asymmetric information itself.

Hypothesis Test Stage and Conclusion Withdrawal

1. Analysis of the effect of $X$ on $Y$ : based on the above analysis, the significance value of $X$ is $0.777>0.05$. So it can be concluded that there is no effect of the quality of accounting information on asymmetric information. This result illustrates that capital market players still use information outside the financial statements (accounting information) in their investment decision making.

2. Analysis of the effect of $X$ on $Z$ : based on the above analysis, a significance value of $X$ of $0.272>0.05$ is obtained. So it can be concluded that there is no influence of the quality of accounting information on the 
cost of capital. This result is also in line with the results of hypothesis 1 above, namely capital market players do not use accounting information as the main source of information in making investment decisions.

3. Analysis of the effect of $\mathrm{Y}$ on $\mathrm{Z}$ : based on the results of the analysis above obtained a significance value of $\mathrm{Y}$ of $0.001<0.05$. So it can be concluded that there is a significant effect of asymmetric information on the cost of capital. These results are in accordance with the hypothesis, and show that the selling price and the purchase price that occur in the market do affect the cost of capital.

4. Analysis of the influence of $\mathrm{X}$ through $\mathrm{Y}$ on $\mathrm{Z}$ : based on the results of the above analysis obtained direct influence given the quality of accounting information on the cost of capital of 0.31 , while the indirect effect of the quality of accounting information through asymmetric information on the cost of capital is the multiplication of beta $\mathrm{X}$ values with respect to $\mathrm{Y}$ with a beta value of $\mathrm{Y}$ with respect to $\mathrm{Z}$, namely: $(-0.008) \mathrm{x}$ $(-0.96)=0.008$

5. Based on the calculation above, it is known that the value of the direct effect is greater than the value of the indirect effect, this shows that the quality of accounting information through asymmetric information has little effect on the cost of capital. While the total effect given by the quality of accounting information on the cost of capital is the direct effect coupled with the indirect effect, namely: $0.31-0.008=0.302$

\section{Conclusions and Suggestions}

From the results of hypothesis testing it is found that: the quality of accounting information has no effect on asymmetric information., the quality of accounting information does not affect the cost of capital., asymmetric information affects the cost of capital., tThe direct effect of the quality of accounting information on the cost of capital is greater than the effect of The quality of accounting information through asymmetric information.

Suggested that regulators and setter standards can continuously improve regulations and financial reporting standards, so that the capital market can become even more efficient.

\section{References}

Amihud, Y., dan H. Mendelson. 1986. Asset pricing and the bid-ask spread. Journal of Financial Economics vol. 17 pp. 233-249.

Barth, et al . 2013. Cost of Capital and Earnings Transparency. Journal of Accounting and Economics vol. 55 pp. 206-224.

Bhattacharya, et al. 2012. Direct and Mediated Associations Among Earnings Quality, Information Asymmetry and the Cost of Equity. The Accounting Review. Vol. 87, No. 2 pp. 449-482.

Bhattacharya, et al. 2013. Does Earnings Quality Affect Information Asymmetry? Evidence from Trading Costs. Contemporary Accounting Research. Vol. 30 No. 2 pp. 482-516.

Botosan, C.A. 1997. Disclosure Level and the Cost of Equity Capital. Accounting Review vol. 72 no. 3 pp. 323 349.

Breton, G., and R. Taffler. 1995. Creative accounting and investment analyst response. Accounting and Business Research vol. 25 no. 98 pp. 81-92.

Diamond, D., and R. Verrecchia. 1991. Disclosure, liquidity, and the cost of capital. Journal of Finance vol. $46 \mathrm{pp}$. 1325-1359.

Dierkens, N. 1991. Information Asymmetry and Equity Issues. Journal Of Financial And Quantitative Analysis. vol. 26 , no. 2 .

Easley, D., and M. O’Hara. 2004. Information and the cost of capital. Journal of Finance vol. 59 pp. 1553-1583. 
Francis, et al. (2005). Disclosure Incentives and Effects on Cost of Capital Around the World. The Accounting Review, vol. 80 no. 4 pp. 25-62.

Hughes, et al. 2007. Information Asymmetry, Diversification, and Cost of Capital. The Accounting Review. Vol. 82, No. 3. pp. 705-729.

Kothari, S.P. 2000. The Role of Financial Reporting in Reducing Financial Risks in the Market Conference Series ; [Proceedings] from Federal Reserve Bank of Boston, vol. 44 pp. 89-112.

Kothari, C.R. 2004. Research Methodology: Methods and Techniques. New Age International Publisher. Second Revised Edition.

Lambert, et al. 2008. Information asymmetry, information precision, and the cost of capital. Working Paper. University of Pennsylvania and University of Chicago.

Leuz, C., dan R. E. Verrecchia. 2005. Firms' Capital Allocation Choices, Information Quality, and the Cost of Capital. Paper is superseded by a working paper entitled "Accounting Information, Disclosure, and the Cost of Capital”, with Rick Lambert and Robert Verrecchia, also available on SSRN)

Myers, S.C., and N.S. Majluf. 1984. Corporate Financing and Investment Decisions when Firms Have Information that Investor Do Not Have. Journal of Financial Economics vol. 13, pp. 187-221.

Sekaran, U. dan R. Bougie. 2013. Research Methods for Business: a Skill Building Approach. John Wiley and Sons Ltd., United Kingdom, $6^{\text {th }}$ edition. 